\title{
Border Cells and Arbuscular Mycorrhizae in Four Amaranthaceae Species
}

\author{
Laura Arriola, Brendan A. Niemira, and Gene R. Safir
}

Department of Botany and Plant Pathology, Michigan State University, East Lansing 48824.

Accepted for publication 18 September 1997.

\begin{abstract}
Arriola, L., Niemira, B. A., and Safir, G. R. 1997. Border cells and arbuscular mycorrhizae in four Amaranthaceae species. Phytopathology $87: 1240-1242$.

Four species from the family Amaranthaceae were studied to determine border cell production and arbuscular mycorrhizal colonization. It was found that border cells, also known as sloughed root cap cells, are

produced by all plant species studied and increase with increasing root length until a maximum number is reached at a root length of $25 \mathrm{~mm}$. However, the increase in border cells with increasing root length is not uniform between species. Arbuscular mycorrhizal root colonization was found in all the Amaranthaceae species, and arbuscular mycorrhizal colonization was positively correlated with maximum border cell production.
\end{abstract}

Border cells (BC) (also referred to as sloughed root cap cells) (3, $7,12,25)$ are found on the root tips of many plant species including economically important species such as cucumber (Cucumis sativus), soybean (Glycine max), pea (Pisum sativum), and petunia (Petunia spp.) $(7,12)$. BC have not been found in plants belonging to the families Brassicaceae and Chenopodiaceae (3). BC are experimentally defined as cells on the root tip that are separate from each other and will disassociate from the root when gently agitated in water (9). BC have also been shown to be present on the root tips of 2-month-old corn (Zea mays) plants growing in soil (25). In more than 15 plant species surveyed, the viability of $\mathrm{BC}$ isolated from young root tips growing in petri plates was determined to be 80 to $100 \%$ (12). Viable BC of alfalfa (Medicago sativa) are capable of redifferentiation to form callus and roots upon culturing (13). $\mathrm{BC}$ can also synthesize and readily exude unique proteins that are not present in the root tip proper (root cap, root meristem, and adjacent cells) (4). These aspects of BC physiology have lead several researchers to speculate that $\mathrm{BC}$ may influence the rhizosphere's microbial population $(7-9,12,20)$. BC have already been shown to influence soil fungi. Motile zoospores of Pythium spp. were preferentially attracted to cotton (Gossypium hirsutum) BC versus root tips after the $\mathrm{BC}$ had been removed (8). BC of corn have also been shown to stimulate the growth of Pseudomonas fluorescens, inhibit the growth of Rhizobium spp. and Escherichia coli, and induce sporulation in Bacillus spp. (7).

Arbuscular mycorrhizae (AM) are ubiquitous soil fungi that are capable of forming mutualistic associations with many plant species (1). AM associations are the most common form of mycorrhizae and found in most angiosperms including most major crop species such as soybean, corn, wheat (Triticum aestivum), potato (Solanum tuberosum), clover (Trifolium repens), and pea $(6,22)$. AM associations are thought to benefit plants primarily through the uptake of nutrients $(16,23)$, although increased disease resistance resulting from AM root colonization has been suggested to be a major factor as well $(16,18,19)$.

There are a few plant families whose members normally do not form AM. The most notable nonmycorrhizal plants are in the family

Corresponding author: G. R. Safir; E-mail address: safir@pilot.msu.edu

Publication no. P-1997-1017-01R

(C) 1997 The American Phytopathological Society
Brassicaceae and Chenopodiaceae (24). Although it has long been thought that plants in the family Amaranthaceae are also nonmycorrhizal, recent research suggests that they may be capable of forming AM associations (17). Their degree of potential AM formation, however, is a matter of ongoing discussion (20). The physiological and ecological factors that determine the mycorrhizal status of a particular plant species or family are not clear. Baylis (2) suggested that the propensity of a plant to form mycorrhizal relationships depends on the structure and morphology of the root system. An alternative hypothesis proposed by Niemira et al. (20) suggests that mycorrhizal capability may correlate with $\mathrm{BC}$ production. This hypothesis predicts that a relatively high degree of AM colonization will have a relatively high level of BC production. Similarly, low (or absent) mycorrhizal colonization would correspond with low (or absent) BC production.

The purposes of this study were to confirm the mycorrhizal status of species in the family Amaranthaceae and to determine the strength of the correlation, if any, between BC production and AM colonization in those species.

\section{MATERIALS AND METHODS}

Mycorrhizal colonization. Four species from the family Amaranthaceae were studied: Gomphrena globosa L. cv. Lilac, Amaranthus tricolor L., Amaranthus caudatus L. (Stokes Seeds, Inc., Buffalo, NY), and Celosia cristata L. cv. Red Velvet (W. Atlee Burpee \& Co., Warminster, PA). Mycorrhizal white clover, Trifolium repens L., was a positive control and nonmycorrhizal field mustard, Brassica campestris L., a negative control. There were two treatments: (i) inoculation with the mycorrhizal fungus Glomus intraradices Schenck and Smith and (ii) noninoculated controls. Each treatment consisted of 10 plants from each of the above six species. Seeds were germinated at $25^{\circ} \mathrm{C}$ in the dark on water agar overlaid with Whatman filter paper (Whatman International, Ltd., Maidstone, England) until the radicle emerged. The noninoculated controls were planted in a 1:1 ( vol/vol) sterile soil and sand mix. The mycorrhizal treatments were composed of seeds that were planted in a 1:1 ( vol/vol) mixture of sterile soil and soil from mycorrhizal pot cultures that contained three spores per $g$ of soil of G. intraradices. The pot cultures were prepared using Sorghum bicolor (L.) Moench and G. intraradices according to the procedure outlined by Brundrett (5). The plants were grown for 8 weeks 
in a $25^{\circ} \mathrm{C}$ growth chamber with $12 \mathrm{~h} / 12 \mathrm{~h}$ (light/dark) cycles and watered as needed with distilled water. Noninoculated plants received one application, at the rate of $20 \mathrm{ml}$ per plant, of $1 / 4$-strength Hoagland's solution (14) 2 weeks after planting. Inoculated plants received $20 \mathrm{ml}$ of $1 / 4$-strength Hoagland's solution minus phosphorus per plant at 2 weeks after planting. At 8 weeks, the plants were harvested and the roots were used to determine mycorrhizal colonization using the methods of Phillips and Hayman (21), with the following modifications. The roots were washed, cleared, and stained with trypan blue. A random sample of each plant's root system was cut into $0.5-$ to $1-\mathrm{cm}$ segments and placed in a petri plate. The root segments were then suspended in a lactoglycerol destaining solution. Mycorrhizal root colonization percent was determined using the gridline intersect method. The root segments were placed on the stage of a dissecting microscope overlaid with a t-grid, and then viewed at $250 \times$ magnification. The total number of root segments that came in contact with the grid were counted, as were the number of roots with signs of mycorrhizal colonization. Presence or absence of vesicles and associated hyphae were the determining factors in establishing percent mycorrhizal colonization. Arbuscules were rarely seen in our stained roots. The ratio of mycorrhizal root segments to total root segments was used to determine the percent mycorrhizal root colonization. Experimental procedures were repeated with similar results.

BC enumeration. Seeds from the same four species of the family Amaranthaceae (Amaranthus tricolor, Amaranthus caudatus, Gomphrena globosa, and Celosia cristata) and the mycorrhizal positive (Trifolium repens) and negative (Brassica campestris) controls were examined for $\mathrm{BC}$ production. $\mathrm{BC}$ were isolated and counted using the method of Hawes and Brigham (10), with the following modifications. Seeds were surface-sterilized with $20 \%$ commercial bleach for $15 \mathrm{~min}$, rinsed three times in distilled water, and germinated under sterile conditions on $2 \%$ water agar overlaid with Whatman filter paper. Seeds were then incubated during germination in the dark at $25^{\circ} \mathrm{C}$ until the radicles were the desired length. $\mathrm{BC}$ production was determined when the radicles were $5,10,15$, 20,25 , and $30 \mathrm{~mm}$ long. BC were isolated by immersing seedling root tips $(\sim 2 \mathrm{~mm})$ into $85 \mu \mathrm{l}$ of sterile distilled water in a microtiter plate well. The root tips were immersed for $1 \mathrm{~min}$, and the water around the roots was gently agitated with a Pasteur pipette. The roots were removed and $15 \mu \mathrm{l}$ of aqueous $0.05 \%$ toluidine blue stain was added, increasing the well volume to $100 \mu \mathrm{l}$. A $10-\mu 1$ aliquot then was removed from each well and placed on a glass

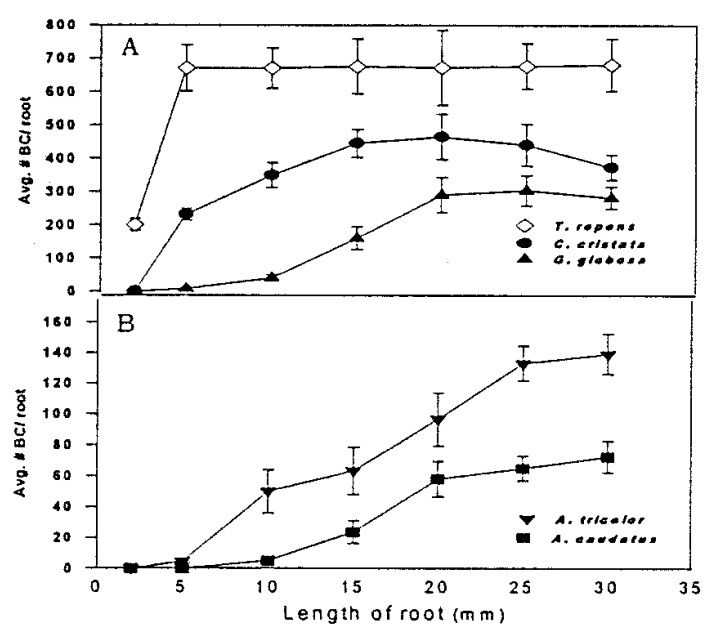

Fig. 1. A, Average number of border cells (BC) per root tip at lengths of 5, $10,15,20,25$, and $30 \mathrm{~mm}$ in Trifolium repens, Celosia cristata, and Gomphrena globosa. B, Average number of BC per root tip at lengths of 5, 10, 15, 20, 25, and $30 \mathrm{~mm}$ for Amaranthus tricolor and Amaranthus caudatus. Note change in scale between $\mathbf{A}$ and $\mathbf{B}$. Bars represent standard error and $n=$ 10 for each point. slide. The $\mathrm{BC}$ in the $10-\mu \mathrm{l}$ aliquot were counted under a dissecting microscope at $500 \times$ magnification, and the total number of BC per well was calculated. Ten seedlings for each species were assessed to determine the average $\mathrm{BC}$ number per root at each length.

Correlation (Pearson product moment) analysis of AM colonization and maximum BC for all species was performed using SigmaStat version 2.0 (Jandel Scientific Software, San Rafael, CA). The experiment was repeated with similar results.

\section{RESULTS}

BC were found in all four Amaranthaceae species as well as the mycorrhizal positive control Trifolium repens. Additionally, the number of $\mathrm{BC}$ increased with increasing root length until a maximum number of $\mathrm{BC}$ per root was reached at $25 \mathrm{~mm}$. This maximum ranged from an average high of $464 \mathrm{BC}$ in Celosia cristata (Fig. 1A) to a low of $72 \mathrm{BC}$ per root in Amaranthus caudatus (Fig. 1B). The mycorrhizal negative control Brassica campestris did not produce $\mathrm{BC}$ until the radicle had reached $30 \mathrm{~mm}$, at which time an average of $4 \mathrm{BC}$ per root was observed; however, most roots did not produce $\mathrm{BC}$. The increase in $\mathrm{BC}$ with increasing root length was not uniform among the species surveyed. Celosia cristata produced approximately $50 \%$ of its maximum number of $\mathrm{BC}$ at $5 \mathrm{~mm}$ in length (Fig. 2A), whereas Gomphrena globosa (Fig. 2A), Amaranthus tricolor, and Amaranthus caudatus had produced 0 to $3 \%$ of their individual maxima (Fig. 2B). Trifolium repens showed maximum BC production at $5 \mathrm{~mm}$ in length (Fig. 2B). For $10-\mathrm{mm}$ roots, Celosia cristata had produced $74 \%$ of maximum and Gomphrena globosa $13 \%$ of maximum (Fig. 2A). At $10 \mathrm{~mm}$ in length, Amaranthus tricolor had produced $36 \%$ and Amaranthus caudatus had produced $7 \%$ of their individual maxima (Fig. 2B).

AM root colonization was found in all the Amaranthaceae species as well as in the positive control Trifolium repens. Celosia cristata had the greatest AM colonization of the family Amaranthaceae and Amaranthus caudatus had the lowest with $47 \%$ and $25 \%$, respectively (Fig. 3). The negative control Brassica campestris was not colonized. Mycorrhizal root colonization was closely and positively correlated with $\mathrm{BC}$ production (Pearson product moment correlation coefficient $=0.906, P=0.0128$ ) (Fig. 3). AM root colonization increased as $\mathrm{BC}$ production increased in the Amaranthaceae species and Trifolium repens.

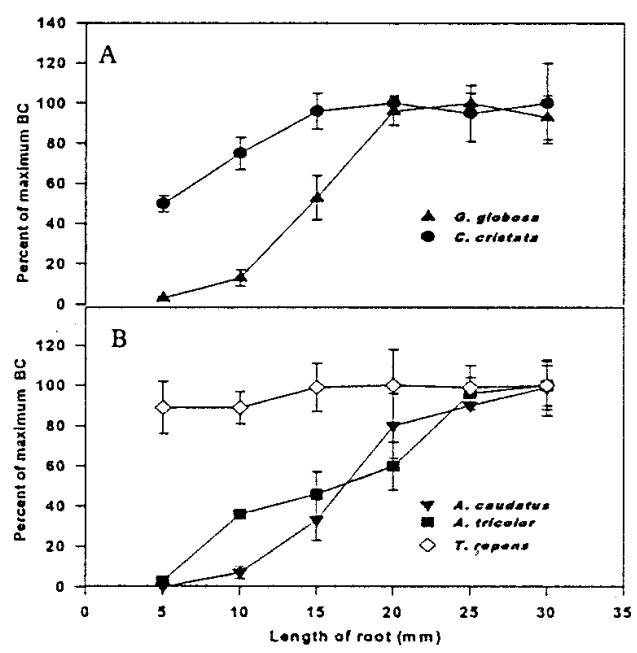

Fig. 2. A, Percent individual species-specific maximum border cells (BC) produced at lengths of 5, 10, 15, 20, 25, and $30 \mathrm{~mm}$ for Gomphrena globosa and Celosia cristata. B, Percent individual species-specific maximum BC produced at lengths of 5, 10, 15, 20, 25, and $30 \mathrm{~mm}$ for Amaranthus caudatus, Amaranthus tricolor, and Trifolium repens. Bars represent standard error and $n=10$ for each point. 


\section{DISCUSSION}

BC production in the family Amaranthaceae was first reported by Hawes and Pueppke (12) in Amaranthus tricolor and Celosia cristata. The results in our study confirm these findings and show that two previously unstudied Amaranthaceae species, Gomphrena globosa and Amaranthus caudatus, also produce BC. Furthermore, the number of BC produced per root increases with increasing length. This was observed in all four of the Amaranthaceae species studied, as well as in the positive control Trifolium repens. Hawes and Lin (11) observed the same phenomena with pea seedlings. They found $\mathrm{BC}$ numbers increasing with increasing root length until the maximum $(3,400 \mathrm{BC}$ per root) was reached at $25 \mathrm{~mm}$. We have shown that the number of $\mathrm{BC}$ at a given root length as a percent of that species maximum is variable between species in the same family and between families, although less variable within a genus. Therefore, comparisons of $\mathrm{BC}$ production per root tip must factor in the length of the roots used. In this study, each species showed maximum BC produced per root tip in roots $25 \mathrm{~mm}$ in length.

We have shown that plants within the family Amaranthaceae are colonized by AM. Neeraj et al. (17) also found that both Amaranthus tricolor and Amaranthus caudatus were colonized by AM. As all four species tested here were readily colonized by AM, it seems likely that mycorrhizal colonization in the family Amaranthaceae is more widespread than was previously believed, and this family should no longer be considered "rarely or minimally" mycorrhizal $(6,20)$, but rather "moderately" mycorrhizal. The level of colonization we observed in these species is roughly comparable to plants in the mycorrhizal family Solanaceae (15).

The hypothesis suggested by Niemira et al. (20), that AM colonization propensity is correlated to BC production, was supported by our results. To more fully test this hypothesis, more research is needed to determine $\mathrm{BC}$ production on actively growing root tips from a wider range of mycorrhizal and nonmycorrhizal plants. Given that BC are known to influence soil fungi of the genus $P y$ thium and bacteria by the synthesis and exudation of stimulatory compounds $(7,8)$, it seems plausible that a similar mechanism may result in the influence of $\mathrm{BC}$ on mycorrhizal soil fungi. Brigham et al. (4) found that $13 \%$ of proteins found in BC were not present in the root tip (root cap, root meristem, and adjacent cells). It is possible that biologically active compounds including those with specific activity towards AM fungi may be produced by the BC. Further research into the specific nature of compounds produced exclusively by $\mathrm{BC}$ may further elucidate the role of $\mathrm{BC}$ in rhizoplane and rhizosphere ecology.

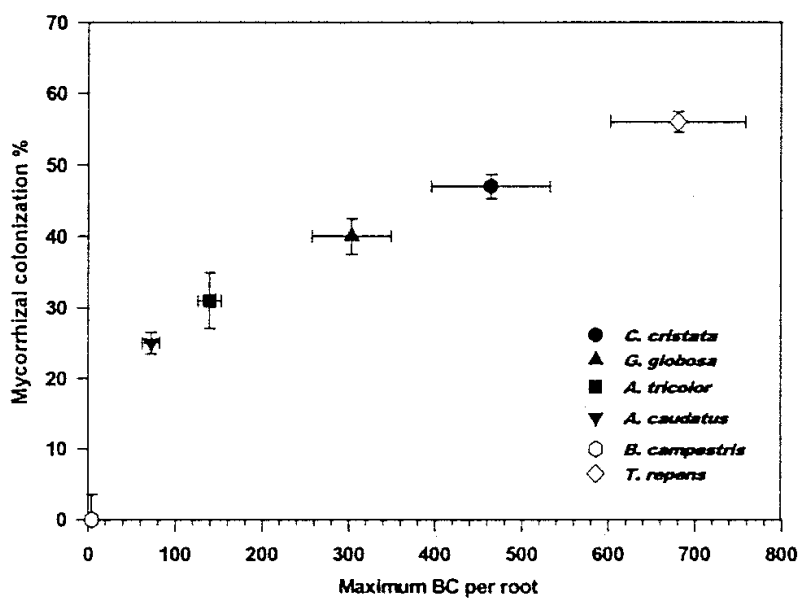

Fig. 3. Arbuscular mycorrhizal root colonization by individual species-specific maximum border cell $(\mathrm{BC})$ production. Pearson product moment correlation coefficient $=0.906, P=0.0128$. Bars represent standard error and $n=$ 10 for each point.

\section{ACKNOWLEDGMENTS}

We thank F. Ewers for technical assistance and review of the manuscript, as well as M. Hausbeck and S. Stephenson for review of the manuscript.

\section{LITERATURE CITED}

1. Bagyaraj, D. J. 1984. VA mycorrhizae: Why all the interest? Pages 1-4 in: VA Mycorrhiza. C. L. Powell and D. J. Bagyaraj, eds. CRC Press, Boca Raton, FL.

2. Baylis, G. T. S. 1975. The magnolioid mycorrhiza and mycotrophy in root systems derived from it. Pages 373-389 in: Endomycorrhizas. F. E. Sanders, B. Mosse, and P. B. Tinker, eds. Academic Press, New York.

3. Brigham, L. A., Woo, H., and Hawes, M. 1995. Root border cells as tools in plant cell studies. Methods Cell Biol. 49:377-387.

4. Brigham, L. A., Woo, H., Nicoll, S. M., and Hawes, M. 1995. Differential expression of proteins and mRNAs from border cells and root tips of pea. Plant Physiol. 109:457-463.

5. Brundrett, M. 1994. Isolating and propagating Glomalean fungi. Pages 7178 in: Practical Methods in Mycorrhiza Research. M. Brundrett, L. Melville, and L. Peterson, eds. Mycologue Publications, Guelph, Ontario, Canada.

6. Gerdemann, J. W. 1968. Vesicular-arbuscular mycorrhiza and plant growth. Annu. Rev. Phytopathol. 6:397-418.

7. Gochnauer, M. B., Sealey, L. J., and McCully, M. E. 1990. Do detached root-cap cells influence bacteria associated with maize roots? Plant Cell Environ. 13:793-801

8. Goldberg, N. P., Hawes, M. C., and Stanghellini, M. E. 1989. Specific attraction to and infection of cotton root cap cells by zoospores of $P y$ thium dissotocum. Can. J. Bot. 67:1760-1767.

9. Hawes, M. C. 1990. Living plant cells released from the root cap: A regulator of microbial populations in the rhizosphere? Plant Soil 129:19-27.

10. Hawes, M. C., and Brigham, L. A. 1992. Impact of root border cells on microbial populations in the rhizosphere. Adv. Plant Pathol. 8:119-148.

11. Hawes, M. C., and Lin, H. 1990. Correlation of pectolytic enzyme activity with the programmed release of cells from root caps of pea (Pisum sativum). Plant Physiol. 94:1855-1856.

12. Hawes, M. C., and Pueppke, S. G. 1986. Sloughed peripheral root cap cells: Yield from different species and callus formation from single cells. Am. J. Bot. 73:1466-1473.

13. Hawes, M. C., Smith, L. Y., and Stephenson, M. 1991. Root organogenesis from single cells released from the root cap of Medicago sp. Plant Cell Tissue Organ Cult. 27:303-308.

14. Hoagland, D. R., and Arnon, D. I. 1950. The water culture method for growing plants without soil. Calif. Agric. Ext. Serv. Circ. 347.

15. Kruckleman, H. W. 1975. Effects of fertilizers, soils, soil tillage and plant species on the frequency of endogone chlamydospores and mycorrhizal infection in arable soils. Pages 511-525 in: Endomycorrhizas. F. E. Sanders, B. Mosse, and P. B. Tinker, eds. Academic Press, New York.

16. Linderman, R. G. 1994. Role of VAM fungi in biocontrol. Pages 1-26 in: Mycorrhizae and Plant Health. F. L. Pfleger and R. G. Linderman, eds. The American Phytopathological Society, St. Paul, MN.

17. Neeraj, A. S., Mathew, J., and Varma, A. 1991. Occurrence of vesiculararbuscular mycorrhizae with Amaranthaceae in soils of the Indian semiarid region. Biol. Fertil. Soils 11:140-144.

18. Newsham, K. K., Fitter, A. H., and Watkinson, A. R. 1993. Arbuscular mycorrhiza protect an annual grass from root pathogenic fungi in the field. J. Ecol. 83:991-1000.

19. Niemira, B. A., Hammerschmidt, R., and Safir, G. R. 1996. Postharvest suppression of potato dry rot (Fusarium sambucinum) in prenuclear minitubers by arbuscular mycorrhizal fungal inoculum. Am. Potato J. 73: 509-515.

20. Niemira, B. A., Safir, G. R., and Hawes, M. C. 1996. Arbuscular mycorrhizal colonization and border cell production: A possible correlation. Phytopathology 86:563-565.

21. Phillips, J. M., and Hayman, D. S. 1970. Improved procedures for clearing roots and staining parasitic and vesicular-arbuscular mycorrhizal fungi for rapid assessment of infection. Trans. Br. Mycol. Soc. 55: 158-161.

22. Safir, G. R. 1994. Involvement of cropping systems, plant produced compounds and inoculum production in the functioning of VAM fungi. Pages 239-260 in: Mycorrhizae and Plant Health. F. L. Pfleger and R. G. Linderman, eds. The American Phytopathological Society, St. Paul, MN.

23. Stribley, D. P. 1987. Mineral nutrition. Pages 59-70 in: Ecophysiology of VA Mycorrhizal Plants. G. R. Safir, ed. CRC Press, Boca Raton, FL.

24. Tester, M., Smith, S. E., and Smith, F. A. 1987. The phenomenon of "nonmycorrhizal" plants. Can. J. Bot. 65:419-431.

25. Vermeer, J., and McCully, M. E. 1982. The rhizosphere in Zea: New insight into its structure and development. Planta 156:45-61. 